\title{
Optimization and Role of Bunda PAUD Village in Efforts to Improve the Quality of PAUD in the District Ogan Komering Ulu Selatan
}

\author{
Istawiah $^{1 *}$, Yasir Arafat ${ }^{2}$, Yenny Puspita ${ }^{2}$ \\ ${ }^{1}$ PAUD Kabupaten OKU Selatan, South of Sumatra, Indonesia \\ ${ }^{2}$ Universitas PGRI Palembang, Indonesia \\ *Corresponding author. Email: Ista76muaradua@gmail.com
}

\begin{abstract}
The goal of this study is to describe, analyze supporting and inhibiting factors and to find solutions to optimize the role of early childhood mothers in the village in an effort to improve the quality of early childhood education in the Ogan Komering Ulu Selatan district. This research is focused on a qualitative descriptive approach. Data collection methods by means of interviews, observation and recording. The results of this study show that the function of PAUD mothers has been optimally performed. This can be seen from the PAUD mothers who knew the roles and functions of being mothers of PAUD, who carried out activities as mothers of PUAD, arranged between mothers of PAUD between villages, districts and districts. As for the support factors for the implementation of the role of PAUD mothers in the Ogan Komering Ulu Selatan District, there is support from the central, provincial and district governments in material and non-material matters, such as support for parents' awareness-raising activities to support early childhood education.
\end{abstract}

Keywords: Optimization, Improving the Standard, PAUD

\section{INTRODUCTION}

As specified in the Law of the Republic of Indonesia No 20 of 2003 on the National Education System Article 28, that: (1) early childhood education shall take place prior to basic education; (2) early childhood education may be coordinated through formal, nonformal and/or informal channels; Pursuant to Permendikbud Number 137 of 2014 on PAUD standards, the child development includes five aspects, namely: religious and moral values, physical, cognitive, linguistic and socio-emotional values. In reaching maturity, each student needs the opportunity to grow and improve a variety of facilities and infrastructure, such as educational games, furniture, sufficient learning/playing space, and a playful environment. At the very least, the facilities and resources available must meet the minimum requirements so that education systems can function well so that the growth and advancement of students can be optimally achieved. Investment in early childhood development is a very significant investment in quality human capital. The efforts to develop human capital are an integrated initiative to improve the quality of education [1]. For this reason, the government continues to strive through Bunda PAUD to pay attention to the implementation of the PAUD programme. PAUD functions to nurture, grow and improve all the ability of children at an early age in an ideal way such that basic attitudes and abilities are developed according to their stage of development in order to be ready for further education [2]. This indicator is seen quantitatively on the situation in Indonesia as follows: low quality due to various determinant variables such as curriculum variable, learning media, lack of facilities, parents and social support, headmaster management, natural environment, less social and cultural support and, last but not least, teacher support [3].

PAUD, as required by Law No. 20 of 2003 on the National Education System, is a coaching effort targeted at children from birth to six years of age, through the provision of educational incentives to promote the physical and spiritual growth and development of children. Be prepared to enter further education. In view of the fact that early childhood is an infant born only 
until the age of 6 years, this age is very decisive in defining the character and personality of the child. At this age, children undergo rapid growth and development, also referred to as the golden age. For their growth and development, a nutritionally healthy diet and intensive stimulation are required. Education is one of the most critical and strategic factors in the growth and improvement of development in all fields, including regions, so that the decentralization of education in the form of regional autonomy cannot be negotiated with a view to improving the quality of education and human capital [4].

Based on data from the PAUD Directorate, the participation rate in early childhood education in Indonesia is very low relative to the participation rate in other countries, almost all of which has reached more than $70 \%$. The participation rate for early childhood education in Indonesia is below $40 \%$ to address this, so it needs well-trained human resources (HR). And efforts need to be tailored (Ministry of Education and Culture, 2020 strategic plan).

There are many potential reasons for the low participation rate in early childhood education in Indonesia. First, public perception of the value of early childhood education (golden years) remains low. Second, there is access to PAUD facilities. Tools are the most important thing to boost the efficiency of the PAUD Directorate. These services are connected to a rise in the professionalism of educators, which is still poor. This needs hard work and support from all stakeholders, including the position of Mother of PAUD.

According to MH Senny, there are eight problems facing PAUD today in 2018. "First is the level of teacher education where only 23.06 percent have a bachelor's degree (S1)," Second, the quality of early childhood services and institutions. Third, there is already a third of children 3-6 years of age who have not accessed PAUD services. Fourth, family engagement has not been compatible with the PAUD institution. "Whereas PAUD is the work of building the nation's foundation and developing children. So, all parties, including parents should support these efforts," Fifthly, PAUD schooling, which should be 80 per cent, is currently based on literacy and numeracy with academic complexities. "This is also a problem, apart from the problem of education investment, the seven problems of nutrition and the eight problems of the status of nonformal PAUD teachers who have not been considered as teachers." Quality education is able to develop positive potentials that are hidden within students.

In line with the above, it is time for PAUD to become a leading agent of the National Early Childhood Movement, an agent of the Family Education Movement and an agent of the I Am Truthful Child Learning Movement. In the future, all PAUDs will be engaged in the One Spirit, One Commitment and One Action Movement.

PAUD has become a concern of different groups, including parents, education experts, culture and the government. Much attention to early childhood education is understandable because numerous research studies have concluded that early childhood learning substantially influences the development of children at a later stage and may improve the efficiency of work in adulthood. However, the culture of PAUD learning, for example in kindergartens, has become an issue in Indonesia in recent years. The problem is that the position of the Bunda PAUD village is not yet optimal due to the low level of human capital in which the Paud Coach's qualifications are high school. Do not recognize the main duties and roles of the Bunda PAUD village in accordance with the guidelines of the Bunda PAUD national.

This is because learning habits tend to be academic, i.e. learning that emphasizes children's ability to read, write, and arithmetic. Learning should not pay attention to the age and stage of development of children. This propensity is attributed, among other factors, to a misunderstanding of the early childhood definition of early learning. In reality, early childhood learning is structured to build all potentials, including physical, cognitive, linguistic, socio-emotional.

The Government continues to foster public knowledge and engagement in the delivery of quality PAUD services. In order to enhance the quality of education services, qualified school principals, educational personnel engaged in teaching and learning activities, including teachers, reliable administrative management, sufficient facilities and community engagement must be assisted [5]. To achieve this, one of the most strategic ways is to promote the role of Bunda PAUD, starting from the National level to the Village/Subdistrict level, as the driving force behind the quality of the National PAUD movement. Bunda PAUD is the title given to the wife of the Head of Government and Regional Heads (President, Governor, Regent/Mayor, Camat, Village Head/Lurah) who is headed by the Head of Government and Regional Head. Bunda PAUD are women who are the key drivers of early childhood education programs 0-6 years of age in support of PAUD quality [6].

Support for the role and involvement of Bunda PAUD, particularly wives (President, Governor, Regent, Village/Subdistrict) is very important in mobilizing all the components and resources in their region to ensure quality early childhood education. Become the optimum.

There are a number of items that become a consideration or context for prospective researchers in making alternative choices for the above-mentioned 
title, namely, there are 315 PAUD institutions registered in Basic Education Details, Disdik 2019, the majority of PAUD institutions are villages whose coaches and concurrently manage PAUD village. The role of Bunda PAUD village in rural areas is not yet optimal, both as Bunda PAUD and as Chair of TP PKK, whose editorial organizer promotes Quality PAUD. The role of Bunda PAUD is currently on the rise in the world of education as well as in the community, as it relates to PAUD Access Services, Quality of PAUD. The title, which is expected later after the completion of the research, is expected to provide solutions to the efforts required to optimize the position of Bunda PAUD, especially in villages and sub-districts.

\section{METHODS}

Analysis is basically a scientific practice designed to gain correct knowledge of the problem. The information obtained is in the form of data, ideas, generalizations and theories that enable researchers to try to understand this phenomenon and to solve the problems at hand. Methodology is a determining factor for the merits of writing scientific papers [7]. In carrying out methodological study, it is important to help the ongoing activities of researchers to evaluate data and solve problems in accordance with the theme being studied and researched. Researchers therefore used qualitative approaches.

The qualitative approach to this study is descriptive. Descriptive research is research into existing phenomena. The method used is the collection and compilation of data, as well as the study and interpretation of the data. In essence, qualitative descriptive research is a method of analyzing the status of a group of individuals, an entity with the intention of making a systematic, factual and accurate descriptive, a picture or a painting of the facts or phenomena being examined. This study is often referred to as postpositivism, ethnographic, grounded and naturalistic research.

With this qualitative analysis, the researcher will discover the real conditions for the outcomes of the research. The research site is the Optimization and Function of Bunda Paud Desa in an Attempt to Improve the Standard of Early Childhood Education (PAUD) at Ogan Komering Regency. Learning facilities and infrastructure that should have been met, although there are some deficiencies, but academic quality is increasing every year so that researchers are interested in conducting research on the Optimization and Role of the Mother Village in the Improvement of Quality of Early Childhood Education (PAUD) in Ogan Komering to the Mother of the Paud in Ogan Komering Ulu.

\section{RESULTS AND DISCUSSION}

Based on the analysis that has been conducted, this indicates that: 1) the capacity of teachers to become more knowledgeable in dealing with students, the expertise and skills of teachers is growing; 2) develop teaching and learning activities in the classroom; 3) parents, as education users, also experience the results. It is shown by the fact that the child's growth is improving, that the child's independence has improved, and that little by little they are able to transcend their special needs; 4) maintaining the standard of current teachers controls, supervises performance, monitors performance on a daily basis, informs the new trends, offers incentives to teachers and others, and 5) the Principal also pays attention to the input of teachers who want emotional preparation and develop facilities and infrastructure, while ensuring good contact with the Foundation, teachers and parents. The introduction of early childhood education is seen through a variety of components, including: curriculum, learning models, facilities and infrastructure. It is appropriate to improve the quality of education, namely: (a) coverage of educational services in terms of quality of education staff, expenses and learning facilities; (b) the consistency of the learning process, which allows students to learn effectively; (c) quality of production in the form of information, attitudes, skills and values.

From the results of the interview, the barriers faced by PAUD managers include educational qualifications, experience, infrastructure, management and welfare. Efforts are being made to enhance the professionalism of PAUD teachers, including the need for scholarship assistance to PAUD teachers, workshops, seminars, appropriate facilities and infrastructure, and to maintain good contact with the foundation, teachers and parents.

\section{Community assistance to Bunda PAUD}

a. To be a Buddy

Active Partners with Schools Parental engagement in PAUD is the secret to the success of PAUD. In this situation, always try to develop good contact with PAUD educators. Child growth is the subject of contact. In consultation, educators can learn about the development encountered by children, both at home and at school. In addition, the meetings were held every semester, while the report cards were received. At the meeting, provide feedback on the growth of PAUD and its students, such as suggesting the inclusion of games.

\section{b. School-Home connect}

When parents monitor the behavior of their children at school. This is achieved when the child is taken to PAUD. Observe his child, too, while waiting. 
c. School Supporters to Achieve Excellent Educational Achievement Parent support/assistance is required in early childhood education. This can be achieved by paying school fees as well as other contributions from parents. With a high degree of parental understanding, superior achievements can be achieved in PAUD.

d. Being actively involved with volunteers as parents strive to build good relationships with volunteers, such as community leaders, with a good relationship between parents and volunteers, volunteers indirectly but continue to provide assistance to PAUD. The goal is to ensure the smooth running of the PAUD. With the proper functioning of leadership management, it is expected that the institutions they lead will witness the growth and enhancement of the standard of education [8].

e. Supporting Educational Priorities Parents must provide educational support to children. It is also hoped that the educational targets will be adequately accomplished. In this situation, people are seeking to fulfill the needs of children in education, such as books and school uniforms. They should also motivate their children to attend school and study diligently. The educational process is a public process [9].

f. Understanding and Understanding of Community Leaders in PAUD Mr. Tarono, as the head of the village, has the impression that early childhood is a child under the age of 6 who still does not understand anything and needs the support and guidance of parents in order to grow up and develop well. PAUD, according to him, is an education that must be given to early childhood as a way to face the next life. The benefits of PAUD are to allow children to grow and develop well and to channel their talents and potential. According to the head of PKBM OKU Selatan, early childhood is a golden age for children, thus early childhood needs to be provided with optimal care and education so that they can grow and develop in an optimal way. PAUD must be extended to children in order to influence children's behaviors, personalities and growth of children's abilities. According to him, the advantages of PAUD are to shape children's attitudes and personalities and to be able to improve children's abilities well. According to Ibu Dwi Aningsih, early childhood is a child who is still below elementary school age and needs to be properly directed, guided and informed. In the meantime, PAUD is an education that must be given to early childhood so that children can grow up and develop properly. The advantages of PAUD are provisions for children to manage their lives.

\section{g. Motivator}

Andarwin (head of the village) has PAUD-motivated kin. He appealed to parents to take part in PAUD. Mr. Tarono was inspired by the socialization of the value of early childhood education to parents. This is done to allow older people to open their hearts to the PAUD. The socialization carried out by Mr. Andarwin obtained a response from the parents, who really engaged in PAUD. First time that socialization was carried out, there were some hurdles in the socialization activity, namely that not all parents followed it, and there was still a lack of understanding among parents.

\section{Supporting and inhibiting the position of PAUD Mothers in the Ogan Kmering Ulu Selatan District}

\section{a. Factor of support}

The support factor for the implementation of the role of PAUD artifacts in the Ogan Komering Ulu Selatan District is support from central, provincial and district governments in material and non-material matters, such as support for parents' awareness-raising activities to support early childhood education.

\section{b. Obstacles element}

The inhibiting factor for the implementation of the role of PAUD mothers in the Ogan Komering Ulu Selatan District, the geographical location of Ogan Komering Ulu Selatan Regency is located in the hills and the distance between the villages is far away and there are still many road accesses which are still in good shape. Apart from that, there is still a lack of learning services, such as book support, interactive learning media, and so on.

3. Sulli for the implementation of the role of PAUD mothers in Ogan Komering Ulu Selatan Regency, among others: a) encouraging community engagement and participation in the promotion and production of quality PAUD services, and b) encouraging owners, administrators, superiors, teachers and employees to provide professional PAUD services; c) optimizing sources of funding to promote the implementation of quality PAUD services in the region by funding sources such as the State Budget (APBN), Municipal Budget (APBD), Village Funds, Corporate Social Responsibility (CSR) and/or other sources. -Other outlets inside the group; d) encouraging expanded access to early childhood education in 3T (Disadvantaged, Frontier and Outermost) areas; e) encouraging the enhancement of the standard of PAUD educators and training workers (qualification, competence, welfare and protection); f) encourage increased oversight in their fields of work, in particular those related to learning materials and educational materials that are free from physical abuse, 
radicalism, pornography, ethnicity, race, religion and between classes; g) encouraging the development of comprehensive holistic PAUD programs, including early childhood care, nursing, nutritional health, education, safety and well-being; h) empowering partner organisations (PAUD technical organizations, PAUD organizations, religious organizations and other community organizations that support the PAUD Quality Programme), and i) promote the readiness of PAUD Unit Organizations to engage in accreditation activities. Quality education is able to develop positive potentials that are hidden within students [10].

\section{CONCLUSION}

The results of research conducted by researchers on the function of mothers in early childhood education (PAUD) in the Ogan Komering Ulu Selatan District show that the role of PAUD mothers has been optimally implemented. As the mother of PUAD, coordinate with other mothers of PAUD between villages, sub-districts and districts. As for the support factors for the implementation of the role of PAUD mothers in the Ogan Komering Ulu Selatan District, there is support from central, provincial and district governments in material and non-material matters, such as support for parents' awareness-raising activities to support early childhood education.

\section{ACKNOWLEDGMENTS}

The author would like to thank Dr. H. Bukman Lian, M.M., M.Si., Chancellor of the PGRI Palembang University, Dr. Syaiful Eddy, M.Sc., Director of the Postgraduate Program at the PGRI Palembang University, Dr. Happy Fitria, M.Pd., Head of Education Management Study Program and all those who have helped morally and materially. May the goodness become multiple good deed.

\section{REFERENCES}

[1] Tobari., Kristiawan, M. \& Asvio, N. (2018). The Strategy of Headmaster on Upgrading Educational Quality in Asean Economic Community (AEC) Era. International Journal of Scientific \& Technology Research 7 (4).

[2] Rozalena., \& Kristiawan, M. (2017). Pengelolaan Pembelajaran Paud Dalam Mengembangkan Potensi Anak Usia Dini [Management of Early Childhood Learning in Developing Early Childhood Potential]. Jurnal Manajemen, Kepemimpinan dan Supervisi Pendidikan 2 (1), Januari-Juni.

DOI:
[3] Wachidi., Rodgers, A., \& Tumanov, D. Y. (2020). Professional Competence Understanding Level of Elementary School in Implementing Curriculum 2013. International Journal of Educational Review Vol. 2, Issue 99-105. Retrieved from https://ejournal.unib.ac.id/index.php/IJER/issue/vie w/814

[4] Rohma, S., Harapan, E., \& Wardiah, D. (2020). The Influence of School-Based Management and Teacher's Professionalism toward Teacher's Performance. Journal of Social Work and Science Education, 1(1), 13-23. Retrieved from https://ejournal.karinosseff.org/index.php/jswse/arti cle/view/6.

[5] Zulaiha, D., Lian, B., \& Mulyadi. (2020). The Effect of Principal's Competence and Community Participation on the Quality of Educational Services. Journal of Social Work and Science Education Volume 1 (1) E-ISSN: 2723-6919.

[6] Departemen Pendidikan Nasional. (2010). Kebijakan Nasional Pembangunan Karakter Bangsa [National Policy for National Character Development]. Jakarta: Depdiknas.

[7] Muttaqin, K., \& Rahmadoni, J. (2020). Analysis and Design of File Security System AES (Advanced Encryption Standard) Cryptography Based. Journal of Applied Engineering and Technological Science (JAETS), 1(2), 113-123. https://doi.org/10.37385/jaets.v1i2.78

[8] Hendriyadi, Ritonga, A. H., \& Us, K. A. (2020). Management Leadership in Improving the Quality of Graduates of Private Islamic Religious Colleges in Jambi Province. International Journal of Progressive Sciences and Technologies (IJPSAT) Vol. 23 No. 2 November 2020, pp. 42-51 Retrieved from https://ijpsat.ijshtjournals.org/index.php/ijpsat/article/view/2308

[9] Maseleno, A., Ayshwary, B., Ivanova, T. N., Hashim, W., Nguyen, P. T., Shankar, K., Kristiawan, M., Huda, M. (2019). General Theoretical and Philosophical Aspects of Modern Education. Aspectos Teóricos y Filosóficos Generales de la Educación Moderna. Revista San Gregorio 2019, No. 32 Special Issues August.

[10] Sarbini., Kristiawan, M., \& Wardiah, D. (2020). Supervisor's Performance for the Quality of Education. International Journal of Progressive Sciences and Technologies (IJPSAT), 20(1), 255 262. 